\title{
KOMPETENSI PEMBUATAN INSTRUMEN PENGUKURAN HASIL BELAJAR OLEH GURU IPS SMP DI KOTA BANDUNG
}

\author{
Mamat Ruhimat \\ Universitas Pendidikan Indonesia \\ Jl. Dr. Setiabudhi No. 299 Bandung, Jawa Barat - Indonesia \\ Email: mamatruhimat@upi.edu
}

\begin{abstract}
Abstrak:
Penelitian ini bertujuan menganalisis kemampuan guru IPS Sekolah Menengah Pertama Kota Bandung dalam membuat alat ukur hasil belajar. Metode penelitian yang digunakan adalah survey. Hasil penelitian menunjukkan bahwa alat ukur bentuk tes lebih dominan digunakan dibandingkan bentuk non tes, baik pada Ulangan Harian, Ujian Tengah Semester (UTS) maupun Ujian Akhir Semester (UAS). Selain itu, hanya sebagian kecil responden guru yang membuat soal dengan mengacu pada kisi-kisi, bahkan ada guru yang tidak membuat kisi-kisi. Alat ukur tes yang dibuat pun tidak melalui tahap uji validitas dan reliabilitas. Responden guru belum menunjukkan peningkatan kualitas dalam pengembangan alat ukur hasil belajar peserta didik. Peneliti merekomendasikan kepada semua pihak terkait untuk melakukan peningkatan, pembiasaan dan pengawasan terhadap guru untuk membuat alat ukur hasil belajar, khususnya bagi guru-guru IPS.
\end{abstract}

\begin{abstract}
:
This study aimed to analyze the ability of the Social Studies Teachers of Junior High School of Bandung city in creating instruments to measure the students' learning outcomes. This research used survey method. The result of this study showed that the test form was more dominant than non-test forms, both on Daily Tests and Middle or Final Semester Exams. In addition, only a few teachers made questions referring to the question framework, and several teachers did not even use it. The instrument also did not pass the validity and reliability test. Teachers had not indicated the quality improvement in developing instrument to measure the students' learning outcomes. Researcher recommended to all relevant parties to improve, habituate and supervise teachers to make learning outcome instruments, especially for Social Studies teachers.
\end{abstract}

\section{Kata kunci: \\ Kompetensi, Instrumen Pengukuran, Hasil Belajar}

PENILAIAN hasil belajar merupakan salah satu komponen penting dalam suatu sistem pembelajaran. Penilaian dan pengukuran merupakan dua hal yang tidak mungkin dapat dipisahkan dari proses pembelajaran dan pendidikan pada umumnya. Penilaian hasil belajar memerlukan alat ukur yang handal, agar mampu mengukur kondisi yang sesungguhnya. Pengukuran, merupakan upaya pencarian informasi atau data dengan menggunakan alat ukur yang sesuai dengan objek yang akan diukur. Hasil pengukuran pada umumnya berupa data dan atau informasi yang cenderung bersifat kuantitatif. Penilaian, merupakan upaya membandingkan hasil pengukuran dengan ukuran tertentu, biasanya bersifat kualitatif. Penilaian, bukanlah 
memberikan hukuman kepada peserta didik, melainkan sebagai data dasar untuk melakukan pembimbingan lebih lanjut. Penilaian, harus didasari hasil pengukuran yang baik. Pengukuran disyaratkan menggunakan alat ukur yang handal. Alat ukur dapat berupa tes maupun non tes. Membuat alat ukur yang handal, tentunya harus dipersiapkan dengan matang, agar dapat mengukur apa yang seharusnya harus diukur. Pengukuran itu merupakan sarana untuk memperoleh data dan atau informasi, sedangkan penilaian merupakan upaya membuat keputusan pendidikan yang harus didasarkan atas hasil pengukuran yang baik.

Pengukuran harus dirancang dengan cermat. Pengukuran dilakukan untuk memperoleh data dan atau informasi yang objektif. Objektifitas dapat dicapai karena pengumpul data mengambil jarak yang tegas dengan objek yang diukur dan menyerahkan wewenang pengukuran kepada alat ukur. Pihak pengukur diharapkan dapat mengikuti regulasi akademik yang bermartabat, termasuk di dalamnya guru IPS. Adanya langkah-langkah di atas, dimaksudkan agar diperoleh alat pengukuran yang baik, pelaksanaan tes yang baik, sehingga akhirnya diperoleh informasi aktual dan objektif untuk dijadikan bahan dasar pembuatan keputusan pendidikan yang adil. Adil, berarti sesuai dengan kondisi objektif hasil pengukuran. Ketika pengukuran peserta didik diawali oleh alat yang tidak baik, dapat dipastikan hasil pengukuran dan keputusan yang dibuatpun tidak akan valid. Alat pengukuran untuk peserta didik dapat berupa tes dan nontes. Tes, dapat diartikan menjadi dua jenis, yaitu: (1) a procedure, reaction, or reagent used to identity or characterize a substance or constituent, (2) something (such as a series of question or exercises) for measuring the skill, knowledge, intelligence, capacities or aptitudes of an individual or group.

Pada lampiran Peraturan Menteri Pendidikan dan Kebudayaan Republik Indonesia Nomor 104 Tahun 2014, telah dijelaskan secara detail, bahkan telah pula dibuat beberapa contoh format instrumen. Hal ini menunjukkan bahwa usaha pemerintah sebenarnya telah optimal untuk membantu para guru. Namun ternyata, tingkat penterjemahan dikalangan para guru tidaklah mudah, kemungkinan disebabkan masing-masing mata pelajaran memiliki karakteristik keilmuan yang berbeda, sementara contoh dari kementerian sifatnya untuk semua mata pelajaran. Mengembangkan instrumen pengukuran sesuai yang diharapkan pihak kementerian tidaklah semudah membalikan telapak tangan. Apalagi dengan Kurikulum 2013 yang mengharapkan para guru untuk dapat menilai tidak hanya terbatas pada domain kognitif semata, melainkan juga sikap dan keterampilan. Kurikulum 2013, sangat menganjurkan dilakukannya penilaian autentik. "Authentic assessment" dalam implementasi Kurikulum 2013 sangatlah diharapkan dapat dilaksanakan oleh para guru. Penilaian autentik adalah penilaian yang nyata dan dibuktikan dengan kinerja dan atau hasil-hasil yang telah dibuat oleh peserta didik (Mustikarani \& Ruhimat, 2018: 149). Untuk memperoleh hasil penilaian otentik dibutuhkan proses pengumpulan data selengkap mungkin sehingga dapat memberikan gambaran perkembangan dan hasil belajar peserta didik (Yani, 2014: 14). Kondisi guru Sekolah Menengah Pertama yang melaksanakan asesmen autentik masih memerlukan 
perbaikan dan kualitas (Kartowagiran \& Jaedun, 2016: 56). Sementara para guru sudah sangat terbiasa mengukur domain kognitif, mengingat ada "anggapan" para guru bahwa Ujian Nasional pun semata-mata hanya mengukur aspek kognitif.

Penilaian hasil belajar peserta didik, biasanya dilakukan oleh para guru dengan berbagai macam tujuan, seperti memantau kemajuan, perkembangan hasil belajar peserta didik sesuai potensi yang dimilikinya. Penilaian yang ideal, sejatinya tidak hanya ditujukan untuk mengukur para peserta didik, melainkan hasilnya dapat dijadikan umpan balik bagi guru untuk memperbaiki proses pembelajaran selanjutnya. Secara umum proses penilaian hasil belajar diperoleh guru selama proses pembelajaran dengan menggunakan alat dan prosedur yang disesuaikan dengan tujuan, standar kompetensi dan berbagai indikator pembelajarannya. Paper and pencil test, sudah sangat biasa dilakukan guru, meskipun perlu diakui bahwa teknik seperti itu bukan satu-satunya alat ukur kompetensi peserta didik. Mengingat luasnya tujuan dan objek penilaian, maka alat ukur yang digunakan dalam penilaian sangat beraneka ragam, tidak hanya terbatas pada tes, tetapi juga alat penialaian lain, yaitu bukan tes. Penilaian unjuk kerja (performance test), project dan juga portofolio, merupakan beberapa tehnik yang perlu dicoba dilakukan oleh para guru. Oleh karena itu, dalam rangka memenuhi kompetensi pedagogik guru dalam aspek penilaian dan evaluasi, setidaknya guru harus mampu membuat instrumen penilaian yang sesuai dengan tujuan, melaksanakan berbagai jenis teknik penilaian dengan berbagai tingkat kesulitan, serta menganalisis hasil penilaian sebagai bahan tindak lanjut proses pembelajaran selanjutnya (Yunus, 2016: 120).

Sebelum lebih jauh memampukan guru pada jenis alat ukur alternatif di luar tes, dipandang perlu adanya pengukuran kemampuan guru, khususnya guru IPS dalam merancang, dan melaksanakan pengukuran hasil belajar peserta didik. Data dan atau informasi kompetensi guru IPS dalam merancang dan melaksanakan pengukuran hasil belajar peserta didik sangat penting untuk diketahui, agar dapat dijadikan data dasar pengembangan kompetensi professional di masa yang akan datang. Penilaian dalam konteks pendidikan, sesungguhnya terkait dengan dua komponen pokok, yaitu tujuan dan pengalaman belajar. Penilaian, tidak hanya diarahkan kepada tujuan-tujuan pendidikan yang telah ditetapkan, tetapi juga terhadap tujuan-tujuan yang tersembunyi, termasuk dampak yang mungkin timbul setelah peserta didik menyelesaikan suatu program tertentu. Penilaian, pengalaman belajar dan tujuan merupakan satu kesatuan utuh. Tujuan, merupakan bagian kesadaran dalam melakukan usaha pendidikan, sehingga pengalaman belajar dan evaluasi akan lebih terarah, sesuai dengan target capaian yang telah ditetapkan. Pengalaman belajar, merupakan aktifitas nyata untuk mencapai tujuan yang telah ditetapkan sejak awal.

Kurikulum 2013, juga mengamanatkan digunakannya Pendekatan Saintifik. Pendekatan pembelajaran saintifik, telah mampu mengalahkan reputasi contextual teaching learning dan cooperative learning. Pendekatan Saintifik telah mendapatkan rekomendasi yang baik dari UNESCO, terutama yang terkait dengan "the four pillars 
of education", yang berupa learning to know, learning to do, learning life together, dan learning to be. Pendekatan saintifik dapat memberikan nuansa student centered learning sehingga proses pembelajaran di kelas dapat beradaptasi dengan perkembangan zaman dan membantu peserta didik mengaktualisasikan dirinya (Kurniawan, Miftahillah, \& Nasihah, 2018: 2). Pendekatan Saintifik pada dasarnya memberi pengalaman kepada peserta didik untuk memperoleh pengetahuan berdasarkan metode ilmiah. Secara konseptual, pendekatan saintifik lebih unggul dari pada konsep eksplorasi, elaborasi dan konfirmasi (EEK), karena pendekatan ini mendorong, bahkan "memaksa" peserta didik untuk aktif mengamati, menanya, mencari data, menyimpulkan dan mengkomunikasikan hasil temuannya (Yani, 2014: 17). Dalam pendekatan saintifik, peserta didik dilatih melakukan kegiatan layaknya sebagai "ilmuwan" yang cara kerjanya menggunakan metode kerja ilmiah.

Pendekatan pembejaran yang diamanatkan Kurikulum 2013 memang bagus, masalahnya adalah tergantung kepada kesiapan guru untuk mengimplementasikannya. Sehebat apapun kurikulum, ketika gurunya tidak berdaya, tetap saja kurikulum yang hebat itu hanya akan menjadi menara gading. Penataan kurikulum memang penting, tetapi pemberdayaan kemampuan akademik guru, jauh lebih penting. Bagi guru-guru IPS yang belum siap, bukan hanya mengikuti sosialisasi dan atau pelatihan, melainkan kemauan untuk mengubah gaya mengajar. Ketika guru IPSnya sendiri tidak memahami dan tidak mampu mengoperasikan saintifik, dipastikan transformasi pengetahuan, sikap dan keterampilan kepada peserta didik yang telah ditetapkan dalam tujuan dan indikator pembelajaran akan mengalami hambatan, bahkan mungkin saja kegagalan. Perubahan kurikulum, tidak sebatas mengubah struktur dan atau susunan materi pelajaran, tetapi juga harus diikuti dengan upaya mengubah mindset para pengajar dan pemangku kepentingan lainnya.

Berdasarkan uraian tersebut, dapat ditarik sebuah kesimpulan bahwa pembuatan instrumen penilaian pada mata pelajaran IPS harus ditunjang oleh kompetensi yang baik. Penyusunan instrumen penelitian membutuhkan proses panjang dan teliti agar menghasilkan instrumen yang valid dan reliabel. Oleh karena itu, penulis bermaksud untuk menganalisis kompetensi guru IPS dalam penyusunan instrumen tes SMP di Kota Bandung.

\section{METODE PENELITIAN}

Metode penelitian yang digunakan adalah survey. Sampel penelitiannya terdiri atas 60 orang guru SMP di Kota Bandung, yang terdiri atas 33 orang (55\%) guru SMP Negeri dan sisanya 27 orang (45\%) guru SMP Swasta. Masing-masing sekolah sampel diwakili oleh satu orang guru IPS. Instrumen penelitian yang digunakan berupa kuesioner, yang ditujukan untuk mengggali respon dan kompetensi guru IPS mengenai ragam aspek pengukuran hasil belajar peserta didik. Kompetensi guru IPS mengenai pengukuran hasil belajar peserta didik, dalam artikel ini dibatasi pada pengembangan instrumen yang dibuat guru, baik untuk ulangan harian, ujian tengah 
semester maupun ujian akhir semester. Data dianalisis secara kuantitatif dan kualitatif. Hasil yang diharapkan adalah terungkapnya kompetensi guru IPS SMP dalam membuat instrumen pengukuran hasil belajar. Materi instrumen penelitian merupakan penelaahan terhadap kualitas alat ukur hasil belajar yang dibuat oleh guru IPS, dilihat dari aspek kisi-kisi, bentuk dan ragam soal tes, bentuk dan ragam soal nontes, pengujian validitas dan reliabilitas, serta pengarsipan naskah soal yang telah digunakan.

\section{HASIL PENELITIAN}

Data hasil penelitian diperoleh melalui penyebaran kuesioner kepada guru IPS SMP Negeri dan Swasta di Kota Bandung. Dalam penelitian ini, data yang diharapkan terungkap adalah kualitas instrumen pengukuran hasil belajar yang dibuat oleh guru, dan pemahaman guru terhadap pendekatan saintifik. Gambaran umum kualitas instrumen pengukuran hasil belajar, terbagi atas dua bagian, yaitu proses pengembangan instrumen dan kualitas instrumen yang dibuat guru. Kegiatan pengukuran hasil belajar dalam penelitian ini terbagi atas 3 bentuk, yaitu ulangan harian, UTS dan UAS pada mata pelajaran ilmu pengetahuan sosial (IPS).

Prosedur standar dalam penyusunan instrumen tes ada empat tahap, yaitu: (1) kisi-kisi tes; (2) soal tes; (3) lembar jawaban; dan (4) pedoman penilaian (Nursalam, Angriani, \& Usman, 2017: 87). Bagian pertama yang ditanyakan kepada responden adalah pembuatan kisi-kisi instrumen. Hasil penelitian menunjukkan bahwa penyusunan kisi-kisi instrumen pengukuran hasil belajar berdasarkan bentuk pengukuran sangatlah bervariasi. Dalam UAS sebagian besar guru $(85 \%)$ menyatakan selalu membuat kisi-kisi, dan 15\% menyatakan sering. Ketika ujian tengah semester, jumlah guru yang selalu membuat kisi-kisi menjadi menurun, yaitu 66\%, dan pada saat ulangan harian ternyata semakin menurun tajam, yakni hanya $35 \%$ guru yang selalu membuat kisi-kisi. Hal kedua yang ditanyakan kepada responden dalam kaitannya dengan penyusunan kisi-kisi instrumen adalah konsistensi pembuatan soal berdasarkan kisi-kisi. Dalam pembuatan soal UAS, 80 \% guru IPS mengatakan selalu didasarkan pada kisi-kisi. Seperti halnya pembuatan kisi-kisi instrumen, persentase guru yang membuat soal didasarkan pada kisi-kisi yang telah dibuat, ternyata pada ujian tengah semester mengalami penurunan, yaitu 65\% guru IPS selalu membuat soal didasarkan pada kisi-kisi. Ketika ulangan harian, ternyata persentasenya semakin menurun lagi, yakni $41 \%$ guru menyatakan bahwa penyusunan soal ulangan harian selalu didasarkan pada kisi-kisi. Bahkan, ada 5 orang guru $(8 \%)$ yang ketika membuat soal ulangan harian tidak pernah didasarkan kepada kisi-kisi. Berdasarkan kecenderungan data hasil penelitian di atas, ternyata sangat jelas bahwa masih ada guru yang membuat soal asal-asalan, tidak didasarkan pada kisi-kisi. Dalam merakit soal, tidak mengacu kepada kisi-kisi, bahkan ada yang tidak membuat kisi-kisi sama sekali.

Selanjutnya, kepada para guru IPS, ditanyakan mengenai pengujian reliabilitas dan validitas. Data hasil penelitian menunjukkan bahwa pada saat ulangan harian, 
hanya sekitar 12 orang (20\%) guru yang selalu melakukan pengujian validitas dan reliabilitas, dan 7 orang (12\%) yang menyatakan tidak pernah, 37 orang (62\%) menyatakan kadang-kadang. Pada UTS jumlah guru yang selalu melakukan uji validitas dan reliabilitas meningkat menjadi 24 orang (40\%), tetapi masih ada 7 orang (12 \%) yang tidak pernah melakukan pengujian. Ketika ujian akhir semester mengalami peningkatan, jumlah guru yang selalu melakukan pengujian validitas dan reliabilitas menjadi 37 orang $(62 \%)$, tetapi masih ada 1 orang $(2 \%)$ yang tidak pernah. Data ini menunjukkan kecenderungan adanya kemungkinan anggapan dari para guru bahwa ujian akhir semester dipandang sangat penting, sehingga jumlah guru yang melakukan pengujian validitas dan reliabilitas makin banyak, meski masih jauh dari harapan ideal. Ulangan harian, kemungkinan dianggap derajat atau levelnya rendah, sehingga dianggap tidak terlalu penting melakukan pengujian validitas dan reliabilitas. Selanjutnya kepada guru ditanyakan pula mengenai pengarsipan dan penggunaan pengulangan soal. Dilihat dari bentuknya, hasil penelitian menunjukkan bahwa soal-soal UAS sebanyak 47 orang (78\%) menyatakan selalu mengarsipkannya, dan tidak ada satu orang gurupun yang tidak mengarsipkannya. Kegiatan mengarsipkan soal makin menurun ketika ujian tengah semester dan ulangan harian. Pada saat ujian tengah semester jumlah yang mengarsipkan soal menurun menjadi 41 orang (68\%), menjadi 39 orang (65\%) pada ulangan harian. Data ini juga menunjukkan kecenderungan bahwa ulangan harian dianggap tidak terlalu penting untuk mengarsipkan soal-soalnya. Di beberapa tempat, kadangkala guru malas membuat soal, sehingga ada kecenderungan untuk menggunakan soal-soal yang telah digunakan untuk digunakan lagi secara berulang-ulang. Hasil penelitian menunjukkan kecenderungan hanya sebagian kecil guru, yaitu 4 orang (7\%) yang selalu menggunakan soal secara berulang-ulang.

Bentuk soal yang dibuat guru IPS juga ditanyakan kecenderungannya. Beberapa bentuk soal yang dibuat guru, baik pada saat ulangan harian, ujian tengah semester maupun ujian akhir semester yang terungkap pada penelitian ini adalah pilihan majemuk, uraian, isian singkat, menjodohkan, dan tes lisan. Hasil penelitian menunjukkan kecenderungan bahwa soal bentuk pilihan majemuk lebih banyak digunakan para guru, yaitu 51 orang (85\%) pada saat ujian akhir semester. Ketika ujian tengah semester, sebanyak 44 orang guru (73\%) selalu menggunakan bentuk pilihan majemuk, dan pada saat ulangan harian, hanya 23 orang (38\%) yang selalu menggunakan bentuk pilihan majemuk. Bentuk soal uraian, juga kecenderungan penggunaannya relative sama dengan bentuk pilihan majemuk, yaitu makin banyak digunakan ketika ujian akhir semester. Ketika ujian akhir semester, sebanyak 29 guru (48\%) menyatakan selalu menggunakan bentuk uraian, kondisinya menurun pada saat ujian tengah semester, yaitu 26 orang (43\%) yang menyatakan selalu menggunakan bentuk uraian. Sementara pada ulangan harian makin menurun lagi, yaitu 21 orang (35\%) menyatakan selalu menggunakan bentuk soal uraian. Bentuk soal menjodohkan, sebagian besar guru menyatakan tidak pernah menggunakannya, baik pada saat ulangan harian, ujian tengah semester maupun pada saat ujian akhir 
semester. Bentuk soal menjodohkan sebanyak 22 orang ( $37 \%$ ) tidak pernah digunakan pada saat ulangan harian, 35 orang (58\%) tidak pernah menggunakannya pada saat ujian tengah semester, dan meningkat menjadi 37 orang $(62 \%)$ tidak pernah menggunakan pada saat ujian akhir semester. Selain bentuk menjodohkan, bentuk soal lain yang paling jarang dilakukan, baik pada saat ulangan harian, ujian tengah semester maupun ujian akhir semester adalah tes lisan.

Selain instrumen pengukuran tes, kepada para guru IPS juga ditanyakan bentuk pengukuran nontes. Dalam penelitian ini terungkap bahwa alat ukur nontes terdiri atas penugasan, skala sikap, observasi, wawancara dan daftar cocok. Hasil penelitian menunjukkan kecenderungan bahwa bentuk soal nontes yang paling banyak digunakan, baik pada ulangan harian, ujian tengah semester maupun pada ujian akhir semester adalah penugasan. Pada ulangan harian sebanyak 32 orang (64\%) mengatakan selalu menggunakan bentuk penugasan. Ketika ujian tengah semester sebanyak 24 orang ( $40 \%$ ) mengatakan selalu menggunakan penugasan, dan pada saat ujian akhir semester sebanyak 25 orang (41\%) memberikan penugasan. Bentuk alat ukur nontes yang paling sedikit digunakan, baik pada saat ulangan harian, ujian tengah semester maupun ujian akhir semester adalah wawancara. Selain itu juga diperoleh data bahwa alat ukur nontes yang berbentuk daftar cocok (checklist), sebagian besar responden menyatakan tidak pernah digunakan. Pada saat ulangan harian, responden yang tidak pernah menggunakan alat ukur daftar cocok sebanyak 29 orang ( $58 \%$ ), ujian tengah semester sebanyak 30 orang (50\%), dan ketika ujian akhir semester sebanyak 33 orang $(66 \%)$. Data hasil penelitian ini mengindikasikan bahwa alat ukur nontes belum banyak dimanfaatkan oleh para guru IPS.

Kepada para guru IPS juga ditanyakan mengenai alat ukur sikap dan keterampilan. Alat ukur sikap yang terungkap dari hasil penelitian ini berupa observasi, penilaian diri, penilaian antar peserta didik, dan jurnal catatan pendidik. Alat ukur aspek keterampilan yang terungkap dari hasil penelitian ini berupa tes praktik, projek dan portofolio. Alat ukur aspek sikap yang sering digunakan guru IPS adalah observasi dan penilaian diri. Sebanyak 26 orang (43\%) menyatakan sering menggunakan observasi, dan sebanyak 30 orang $(50 \%)$ menyatakan sering menggunakan penilaian antar peserta didik. Sebanyak 24 orang $(40 \%)$ menyatakan selalu menggunakan tes praktek untuk mengukur aspek keterampilan, dan sebanyak 17 orang (28\%) menyatakan selalu menggunakan projek. Seperti halnya alat ukur aspek sikap, alat ukur aspek keterampilanpun masih belum banyak digunakan. Hal ini berarti bahwa tes masih digunakan sebagai bentuk alat ukur yang dominan sampai sekarang ini. Bentuk alat ukur non tes hanya digunakan secara temporer saja, dalam artian belum memperhitungkan tujuan dan indikator pembelajaran IPS yang sesungguhnya. Observasi, paling banyak dipilih oleh para guru IPS sebagai alat ukur non tes untuk mengukur aspek keterampilan. 


\section{PEMBAHASAN}

Hasil penelitian secara umum menggambarkan bahwa para guru IPS SMP masih belum melakukan perubahan sikap dalam pengukuran dan penilain hasil belajar peserta didiknya. Masih ada guru yang tidak pernah membuat kisi-kisi, dan kalaupun ada yang membuat kisi-kisi, namun tidak selamanya konstruksi alat ukur itu tidak didasarkan atas kisi-kisi yang telah dibuatnya. Bentuk soal pilihan majemuk dan penggunaan soal secara berulang, juga masih merupakan kultur lama yang terungkap dari hasil penelitian ini. Kisi-kisi atau table spesifikasi itu sangat penting dalam mengkonstruksi alat ukur, karena dapat dijadikan pedoman, terutama mengenai jumlah, bentuk, jenis dan tingkat kesukaran item (Purwanto, 2014: 39). Mengkonstruksi alat ukur hasil belajar, sejatinya tidak dibuat asal-asalan, tetapi harus memperhitungkan banyak hal. Pemerintah, hendaknya melakukan sosialisasi dan pelatihan membuat kisi-kisi dahulu, baru membuat soal-soal, bukan malah sebaliknya (Setiadi, 2016: 76). Hasil penelitian juga memperlihatkan kecenderungan bahwa para guru IPS sangat jarang, bahkan ada yang menjawab tidak pernah melakukan uji validitas dan reliabilitas. Dilihat dari bentuk ujiannya, hasil penelitian menunjukkan bahwa pengujian validitas dan reliabilitas lebih banyak digunakan untuk soal-soal ujian akhir semester. Padahal, uji validitas dan reliabilitas merupakan dua hal penting untuk mengontrol kualitas alat yang digunakan. Analisis soal, sebenarnya tidak hanya dilakukan setelah alat itu diujicoba. Sebelum alat diujikan sebaiknya ditelaah terlebih dahulu, terutama yang berkaitan dengan kesesuaian soal dengan tujuan dan indikator pembelajaran, kesesuaian jumlah soal, serta kebenaran konsep-konsep yang diujikan (Purwanto, 2014: 53).

Seperti halnya validitas dan reliabilitas, informasi pengarsipan soalpun menunjukkan kecenderungan yang relatif sama. Soal-soal ujian akhir semester lebih banyak diarsipkan dari pada soal-soal ujian tengah semester dan ulangan harian. Hal ini juga mengindikasikan bahwa ujian akhir semester masih diposisikan lebih tinggi derajatnya dibandingkan dengan ujian tengah semester dan ulangan harian. Soal-soal bekas ujian akhir semester, pada umumnya masih digunakan untuk melatih persiapan pengukuran kompetesi peserta didik menjelang even-even yang lebih penting. Namun pihak sekolah perlu mengamankannya, jangan terlalu sering dipakai secara berulang-ulang dalam situasi pengukuran yang formal, sebab soal yang telah digunakan sesungguhnya telah bias. Soal yang bias sudah pasti tingkat kehandalannya relatif rendah.

Selain alat ukur tes, juga terungkap penggunaan alat ukur nontes. Alat ukur nontes digunakan untuk mengukur aspek sikap dan keterampilan. Alat ukur aspek sikap yang paling banyak digunakan guru IPS adalah pedoman observasi. Tidak ada satupun responden yang pernah menggunakan penilaian antar peserta didik atau asesmen rekan sebaya. Pengukuran dengan menggunakan asesmen rekan sebaya, sebenarnya dapat dicoba dijadikan salah satu alternatif. Melatih kejujuran dan objektivitas, dapat dilakukan melalui asesmen rekan sebaya. Alat ukur aspek keterampilan yang banyak digunakan adalah bentuk penugasan. Penggunaan alat 
ukur nontes, sesungguhnya dapat dijadikan sarana untuk mendapatkan informasi sebanyak mungkin mengenai perkembangan kemajuan peserta didik. Masih minim dan belum terbiasanya menggunakan alat ukur non tes menunjukkan masih lemahnya kesiapan para guru untuk mengimplementasikan penilaian autentik dalam Kurikulum 2013. Pengukuran sikap dan juga keterampilan, nampaknya harus mulai dihidupkan dan dibudayakan kembali. Banyak pihak yang mengatakan bahwa pendidikan dan pembelajaran, tidak sekadar transformasi pengetahuan, melainkan juga transformasi sikap dan pengembangan keterampilan. Bidang studi IPS di SMP bersifat synthesize disciplines, berupa pemaduan konsep-konsep ilmu pendidikan, permasalahan social yang berkaitan dengan sikap, nilai, dan berbagai permasalahan actual di masyarakat (Somantri, 2001: 143). Menurut National Council for Social Studies dalam Somantri (2001: 144), IPS itu bukan ilmu, melainkan studi integratif dari ilmuilmu sosial dan kemanusiaan untuk mengembangkan peserta didik menjadi warga negara yang baik. Pembelajaran IPS tanpa transformasi nilai dan sikap sangatlah kering, karena hanya bersifat pemindahan pengetahuan dari guru kepada peserta didik. IPS, diidentikan pula sebagai studi yang memperhatikan usaha manusia membangun kehidupan yang lebih baik bagi dirinya, anggota keluarganya, solusi terhadap sejumlah permasalahan sosial, bagaimana orang dapat hidup bersama secara rukun di tengah-tengah keberagaman, bagaimana orang mengubah dan diubah oleh lingkungannya.

Ilmu-ilmu sosial dan IPS hadir karena tidak semua permasalahan kehidupan dapat dipecahkan melalui ilmu-ilmu alam dan IPA semata. IPS, merupakan interrelasi ilmu-ilmu social dalam menelaah gejala dan masalah sosial yang terjadi di tengah-tengah masyarakat. Menelaah gejala dan masalah sosial, dipastikan tidak hanya cukup sebatas menggunakan alat ukur pilihan ganda, dan hanya ada satu jawaban yang benar. Kebenaran di IPS itu sesungguhnya tidaklah tunggal, peserta didik diberi kebebasan mengembangkan kreatifitas jawaban selama dalam koridor yang positif. Menurut Gross dalam Solihatin dan Raharjo (2011: 151), tujuan IPS adalah to prepare students to be well functioning citizens in a democratic society. Kegiatan pengukuran dan evaluasi merupakan bagian yang tidak terpisahkan dari proses pembelajaran. Jaminan kualitas pencapaian sangatlah penting, dan hanya evaluasi yang benar hal tersebut dapat diketahui. Guru memegang peran sangat penting dalam melakukan evaluasi. Bila guru belum memahaminya, perlu segera dilakukan pembinaan. Pola pembinanan guru lebih diarahkan kepada penumbuhkembangan kreatifitas dari pada pelatihan yang bersifat administratif (Yani, 2016: 96). Jadi, kualitas proses pembelajaran dan kualitas kemampuan peserta didik sebagaimana telah digariskan pada tujuan dan indikator pembelajaran, idealnya dapat diperoleh melalui proses pengukuran dan penilaian yang baik pula. Kondisi guru IPS di bidang lain juga masih kurang baik, hanya 20\% yang memahami konsep literasi geografi (Sugiyanto, Maryani, \& Ruhimat, 2017: 75).

Penelitian kemampuan guru untuk mengkonstruksi alat pengukuran dan penilaian hasil belajar, nampaknya masih perlu terus diteliti, karena pengukuran dan 
evaluasi merupakan bagian yang tidak terpisahkan dari proses pembelajaran. Mau bagaimana menghasilkan data kemampuan atau kompetensi riil peserta didik yang terpercaya ketika alat ukur yang digunakannyapun tidak handal. Oleh karena itu meningkatkan kualifikasi guru IPS dalam mengkonstruksi, mengujicoba dan menganalisis alat ukur hasil belajar merupakan kegiatan yang penting untuk dilakukan, apalagi ketika implementasi Kurikulum 2013. Kurikulum 2013, dengan sangat jelas mensyaratkan penggunaan penilaian autentik. Pengembangan instrumen pengukuran pembelajaran semakin variatif, tidak hanya sebatas apek kognitif, melainkan juga aspek lain, seperti halnya kemampuan sosial dan komunikasi. Kemampuan guru untuk membuat alat ukur yang baik merupakan karya yang perlu diapreasiasi. Seringkali karya-karya guru terabaikan, dimana karya mereka itu seakan-akan menjadi makhluk tak bertuan (Komara, 2016: 43). Ketika kita akan melakukan penilaian autentik, sejatinya proses pembelajarannyapun bersifat autentik juga. Ruang lingkup aspek yang dinilai mencakup kompetensi sikap, pengetahuan dan keterampilan (Kemendikbud, 2014). Dalam pengembangan alat ukur dan evaluasi setidaknya ada tujuh komponen yang perlu diperhatikan serius, yaitu pendekatan evaluasi, tujuan dan fungsi evaluasi yang dikembangkan, ruang lingkup aspek yang dinilai, acuan penilaian dan parameter pencapaian kompetensi, mekanisme dan waktu pelaksanaan evaluasi, pengembangan dan pengujian instrumen, dan penetapan keputusan pendidikan dari hasil penilaian. Pelaksanaan uji kompetensi juga dapat dilakukan dengan banyak cara. There were variations in the implementation of examination rules and regulation by lectures (Shariffuddin, 2009: 176). Pendekatan evaluasi terdiri atas pendekatan tradisional dan pendekatan sistem. Pendekatan tradisional, merupakan pendekatan yang selama ini telah terbiasa dilaksanakan. Pendekatan sistem, merupakan pendekatan yang ditujukan kepada proses penilaian totalitas dari berbagai komponen yang saling berhubungan (Arifin, 2010: 112). Penelitian mengenai kemampuan guru IPS dalam mengembangkan alat ukur hasil belajar masih relative jarang. Selama ini penelitian Pembelajaran IPS yang relative banyak sampai saat ini adalah pengembangan model, strategi dan tehnik pembelajaran. Padahal meneliti mengenai kemampuan guru IPS dalam mengkonstruksi alat ukur hasil belajar juga tidak kalah penting, dan harus dilakukan.

\section{SIMPULAN}

Kualitas instrumen pengukuran hasil belajar yang dibuat guru-guru IPS dapat diperhatikan dari proses pengkontruksiannya. Secara umum dapat disimpulkan bahwa kualitas alat ukur yang biasa dikembangkan guru-guru IPS masih sangat perlu ditingkatkan kualitasnya. Kualitas alat ukur hasil belajar yang selama ini dikembangkan oleh para guru IPS masih diragukan kehandalannya. Sebelum mengkonstruksi alat, masih ada guru-guru IPS yang tidak membuat kisi-kisi, kalaupun ada yang telah membuat kisi-kisi, ternyata masih ada pula yang pengembangan soalnya tidak didasarkan kepada kisi-kisi yang telah dibuat. Bentuk alat ukur tes paling sering digunakan dibandingkan alat ukur non tes. Bentuk alat tes, 
tipe pilihan majemuk paling banyak digunakan, baik pada saat ulangan harian, ujian tengah semester maupun ujian akhir semester. Alat ukur aspek sikap dan keterampilan tidak banyak digunakan. Alat ukur non tes yang paling banyak digunakan adalah pedoman observasi. Kultur yang tidak biasa menggunakan alat ukur non tes, dipastikan sangat tidak mendukung implementasi Kurikulum 2013. Kurikulum 2013, mewajibkan penggunaan penilaian autentik, aspek sikap dan keterampilan sama sekali tidak boleh dimarginalisasikan. Memarginalkan aspek sikap dan keterampilan dalam pendidikan, sama saja dengan mendzholimi tujuan normative pendidikan itu sendiri. Dalam pengembangan alat ukur, pengujian tingkat validitas dan reliabilitas juga tidak banyak dilakukan. Berdasarkan pada kecenderungan data hasil penelitian, nampaknya guru-guru IPS masih belum mengalami perubahan sikap yang menggembirakan dalam pengembangan alat ukur hasil belajar. Sehebat apapun kurikulum dan perangkat pembelajaran, tidak mungkin akan dapat mencapai sasaran yang telah ditetapkan, ketika gurunya tidak berdaya. Oleh karena itu pemberdayaan guru, khususnya pemberdayaan kompetensi mengembangkan alat ukur hasil belajar diharapkan mendapatkan perhatian serius dari berbagai pihak terkait.

\section{DAFTAR PUSTAKA}

Arifin, Z. (2010). Evaluasi Pembelajaran. Bandung: PT Remaja Rosdakarya.

Kartowagiran, B., \& Jaedun, A. (2016). Model Asesmen Autentik untuk Menilai Hasil Belajar Siswa Sekolah Menengah Pertama. Jurnal Penelitian Dan Evaluasi Pendidikan, 20(2), 131-141. Retrieved

from https://journal.uny.ac.id/index.php/jpep/article/view/10063/8450

Kemendikbud. (2014). Permendikbud Nomor 104 Tahun 2014 tentang Penilaian Hasil Belajar oleh Pendidik pada Pendidikan Dasar dan pendidikan Menengah. Jakarta: Kemendikbud.

Komara, E. (2016). Perlindungan Profesi Guru di Indonesia. Mimbar Pendidikan: Jurnal Indonesia Untuk Kajian Pendidikan, 1(2), 151-160. Retrieved from https://www.researchgate.net/publication/313543106_Perlindungan_Profesi_Guru_di_ Indonesia

Kurniawan, M. A., Miftahillah, A., \& Nasihah, N. M. (2018). Pembelajaran Berbasis StudentCentered Learning di Perguruan Tinggi: Suatu Tinjauan di UIN Sunan Kalijaga Yogyakarta. Lentera Pendidikan, 2l(1), $1-11$. https://doi.org/https://doi.org/10.24252/lp.2018v21n1i1

Mustikarani, W., \& Ruhimat, M. (2018). Kelemahan dan Keunggulan Implementasi Authentic Assessment dalam Pembelajaran Geografi. Jurnal Gea, 8(2), 147-153. Retrieved from http://ejournal.upi.edu/index.php/gea/article/view/13526/7976

Nursalam, Angriani, A. D., \& Usman, H. (2017). Pengembangan Tes Kemampuan Penalaran Matematis Peserta Didik Madrasah Tsanawiyah di Makassar. Lentera Pendidikan, 20(1), 1-11. Retrieved from http://journal.uinalauddin.ac.id/index.php/lentera_pendidikan/article/view/3959/5366 
Purwanto, E. (2014). Evaluasi Proses dan Hasil dalam Pembelajaran: Aplikasi dalam Bidang Studi Geografi. Yogyakarta: Ombak.

Setiadi, H. (2016). Pelaksanaan Penilaian Pada Kurikulum 2013. Jurnal Penelitian Dan Evaluasi Pendidikan, 20(2), 166-178. Retrieved from https://journal.uny.ac.id/index.php/jpep/article/view/7173/8446

Shariffuddin, S. A. (2009). Cheating in Examinations: A Study of Academic Dishonesty in A Malaysia College. ASIAN Journal of University Education, 5(2), 99 - 124. Retrieved from

https://www.researchgate.net/publication/284714447_Cheating_in_Examinations_A_S tudy_of_Academic_Dishonesty_in_a_Malaysian_College

Solihatin, E., \& Raharjo. (2011). Cooperative Learning Analisis Model Pembelajaran IPS. Jakarta: Bumi Aksara.

Somantri, M. N. (2001). Menggagas Pembaharuan Pendidikan IPS. Bandung: Program Pascasarjana dan Fakultas Pendidikan Ilmu Pengetahuan Sosial Universitas Pendidikan Indonesia Kerjasama dengan Remaja Rosdakarya.

Sugiyanto, Maryani, E., \& Ruhimat, M. (2017). Studi Tingkat Kepahaman Guru IPS tentang Literasi Geografi. Jurnal Pendidikan Ilmu Sosial, 26(2), 205-218. Retrieved from http://ejournal.upi.edu/index.php/jpis/article/download/8568/pdf

Yani, A. (2014). Mindset Kurikulum 2013. Bandung: Alfabeta.

Yani, A. (2016). Penundaan Implementasi Kurikulum 2013 di Indonesia; Perspektif Budaya dan Sosial-Politik di Era Kabinet Jokowi-JK. Jurnal Sosiohumanika: Jurnal Pendidikan Sains Sosial Dan Kemanusiaan, 9(1), 153 - 172. Retrieved from https://anzdoc.com/penundaan-implementasi-kurikulum-2013-di-indonesiaperspekti.html

Yunus, M. (2016). Profesionalisme Guru dalam Peningkatan Mutu Pendidikan. Lentera Pendidikan, 19(1), 112-128. Retrieved from http://journal.uinalauddin.ac.id/index.php/lentera_pendidikan/article/view/2074/1999 